\title{
Residual Phosphorus and Zinc Influence on Succeeding Pearl Millet (Pennisetum glaucum) under Rainfed Conditions of Arid Region of Rajasthan
}

\author{
S. Kumawat*, R. Sammauria and Kumawat Pushpa \\ Rajasthan Agriculture Research Institute, Durgapura (SKNAU, Jobner), \\ Rajasthan 302018, India \\ *Corresponding author
}

\begin{abstract}
A B S T R A C T
Keywords

Nutrient uptake, Pearl millet, Phosphorus,

Yield, Zinc and Zinc solubilizer

Article Info

Accepted:

08 August 2018

Available Online:

10 September 2018

A field experiment was conducted in split plot design with three replications, during rainy seasons of 2016 and 2017 at Rajasthan Agriculture Research Institute, Durgapura to study the growth, productivity and economics of fenugreek - pearl millet cropping system by using four levels of phosphorus $\left(0,20,40\right.$ and $\left.60 \mathrm{~kg} \mathrm{P}_{2} \mathrm{O}_{5} / \mathrm{ha}\right)$ and six treatments of zinc and zinc solubilizer [0, 2.5 and $5.0 \mathrm{~kg} \mathrm{Zn} / \mathrm{ha}$, zinc solubilizer (Bacillus endophyticus), 2.5 $\mathrm{kg} \mathrm{Zn/ha} \mathrm{+} \mathrm{zinc} \mathrm{solubilizer} \mathrm{and} 5 \mathrm{~kg} \mathrm{Zn/ha} \mathrm{+} \mathrm{zinc} \mathrm{solubilizer]} \mathrm{applied} \mathrm{to} \mathrm{fenugreek.} \mathrm{Results}$ revealed that residual effects of $60 \mathrm{~kg} \mathrm{P}_{2} \mathrm{O}_{5} / \mathrm{ha}$ and $5 \mathrm{~kg} \mathrm{Zn} / \mathrm{ha}+$ zinc solubilizer applied to fenugreek increased grain yield of pearl millet by 52 and $46 \%$, respectively. Residual effect of different levels of phosphorous and zinc significantly increased the nitrogen and phosphorous contents and uptake by pearl millet grain and stover, up to $60 \mathrm{~kg} \mathrm{P}_{2} \mathrm{O}_{5} / \mathrm{ha}$ and $5 \mathrm{~kg} \mathrm{Zn/ha} \mathrm{+} \mathrm{zinc} \mathrm{solubilizer,} \mathrm{however,} \mathrm{Increasing} \mathrm{level} \mathrm{of} \mathrm{residual} \mathrm{phosphorous} \mathrm{had}$ depressive effect on zinc content of grain and stover. The effect of $5 \mathrm{~kg} \mathrm{Zn} / \mathrm{ha}+\mathrm{zinc}$ solubilizer was at par with $2.5 \mathrm{~kg} \mathrm{Zn} / \mathrm{ha}+$ zinc solubilizer.
\end{abstract}

\section{Introduction}

Pearl millet is a drought and heat tolerant warm season cereal crop of the arid and semiarid regions of the north western India where it is grown under conditions of scant and uncertain distribution of rainfalls on very poor supporting soils. The soils of this region are moderately deficient in phosphorus and zinc and its external application is required for optimization of productivity. Phosphorus plays an important role in root development and proliferation thus it influences nutrient and water uptake by plants. It is also known to enhance the symbiotic nitrogen fixation by increasing nitrogenase activity of root nodules and plays an important role in energy transfer process in the plant (Mehta et al., 2011). Out of applied zinc fertilizer, only 3 to $6 \%$ is utilized by first crop so the fertilizer added once to soil leaves significant residual effects for the succeeding crops (Patel et al., 2003) and it is not necessary to apply zinc to every crop in zinc deficient soils (Taker, 1996). As indicated above that sizable amount of applied fertilizer nutrients of both phosphorous and zinc remain present in soil in insoluble / unavailable form, therefore, instead of giving 
more fertilizers to cater crop needs, efforts must be made to utilize insoluble / unavailable form of both phosphorous and zinc in soil. Microbes are potential alternate that may cater plant zinc requirement by solubilising the complex zinc in soil. It has also been reported that phosphorous is to be applied on system basis and it is more beneficial to apply it in winter season component rather than rainy season (Raju et al., 2005 and Jat and Shaktawat, 2003). Therefore, it was of utmost importance to study the residual effect of fenugreek fertilized with phosphorous and zinc and zinc solubilizer on the succeeding pearl millet.

\section{Materials and Methods}

\section{Experimental details}

The experiment was conducted at research farm of Rajasthan Agriculture Research Institute-Durgapura (SKNAU, Jobner) during the rainy seasons of the years 2016 and 2017. The soil was loamy sand, low in available nitrogen and phosphorous, medium in potassium and low in zinc content (139.2, 26.6, $182 \mathrm{~kg} / \mathrm{ha}$ and $0.37 \mathrm{ppm}$ ) during 2015-16 and $(134.2,24.5,180 \mathrm{~kg} / \mathrm{ha}$ and $0.35 \mathrm{ppm})$ during 2015-16, respectively in $0-30 \mathrm{~cm}$ soil depth. The soil $\mathrm{pH}$ was 8.3 and 8.1 and per cent organic carbon content was 0.17 and 0.14 $\%$ with respective years. Treatments comprised of twenty four treatment combinations consisting of four phosphorous levels $\left(0,20,40\right.$ and $\left.60 \mathrm{~kg} \mathrm{P}_{2} \mathrm{O}_{5} / \mathrm{ha}\right)$ as main plot treatments and six zinc treatments $(0,2.5$, $5.0 \mathrm{~kg} \mathrm{Zn/ha,} \mathrm{zinc} \mathrm{solubilizer} \mathrm{(Bacillus}$ endophyticus), $2.5 \mathrm{~kg} \mathrm{Zn/ha} \mathrm{+} \mathrm{zinc} \mathrm{solubilizer}$ and $5 \mathrm{~kg} \mathrm{Zn/ha} \mathrm{+} \mathrm{zinc} \mathrm{solubilizer)} \mathrm{as} \mathrm{sub} \mathrm{plot}$ treatments were tested in split plot design with three replications. A uniform dose of $20 \mathrm{~kg}$ $\mathrm{N} /$ ha along with phosphorous and zinc as per treatment were drilled through diammonium phosphate and zinc sulphate (21\%), respectively. To compensate the sulphur obtained from different levels of zinc compensatory dose of sulphur applied through elemental sulphur. To assess the residual effect of phosphorous and zinc treatments applied to preceding crop, succeeding crop of pearl millet (var. RHB 177) was raised, during kharif seasons of 2016 and 2017 in same lay out and was sown on 18 July 2016 and 20 July 2017, respectively. Recommended dose of nitrogen $(90 \mathrm{~kg} / \mathrm{ha}$ ) was applied to pearl millet in two splits, half as basal and remaining as top dress at 30 days after sowing and no other nutrient was applied. Not a major insect/disease was observed during the life cycle of fenugreek in the experiment, but weeds were manually controlled twice (30 and 58 days after sowing). Economics of treatments were worked out using market price of inputs and minimum support price of outputs. Nutrient content in seed and straw for working out total uptake of the nutrients were estimated by the standard methods.

Nutrient uptake (for NPK) $(\mathrm{kg} / \mathrm{ha})=[$ Nutrient content in seed (\%) $x$ Seed yield $(\mathrm{kg} / \mathrm{ha})+$ Nutrient content in straw (\%) x Straw yield (kg/ha) ] / 100

Nutrient uptake (for Zn) (g/ha) = [Nutrient content in seed $(\mathrm{ppm}) \times$ Seed yield $(\mathrm{kg} / \mathrm{ha})+$ Nutrient content in straw (ppm) x Straw yield (kg/ha)] / 1000

\section{Environmental conditions}

The total number of rainy days (32 days) was higher, during 2016 as compared to, during 2017 (24 days). Besides, the total amount of rainfall received, during $2016(402.8 \mathrm{~mm})$ was higher in amount and relatively well distributed than that of obtained, during 2017 (348.4 mm), as it is evidenced by dry spells of 7 days occurred for three times, during 2016, however, during 2017 these dry spells received for five times (Fig. 1). Similarly, evaporation rate was also lower, during ear 
emergence stage of crop growth, during 2016 as compared to, during 2017. Onset of rainfall, its amount and distribution with favorable temperature and better atmospheric humidity greatly influenced the performance of pearl millet to a great extent, thus productivity levels were higher during 2016.

\section{Results and Discussion}

\section{Yield}

The grain, stover and biological yields of pearl millet were significantly influenced up to 60 $\mathrm{kg} \mathrm{P}_{2} \mathrm{O}_{5} / \mathrm{ha}$, during both the years might be due to that considerable portion of the phosphorus applied to fenugreek crop, might have remained in the soil in the forms of various phosphorus compounds, which had considerable nourishing effect on the succeeding pearl millet. Certain grain crops may be able to mobilize residual phosphorus through root exudates, and thus increase their own growth. The residual effect of zinc treatments significantly influenced yield of pearl millet, over control except zinc solubilizer, during both the years in stover and biological yields. The residual effect of $5 \mathrm{~kg}$ $\mathrm{Zn} / \mathrm{ha}$ was significantly better than that of 2.5 $\mathrm{kg} \mathrm{Zn/ha} \mathrm{and} \mathrm{zinc} \mathrm{solublizer} \mathrm{but} \mathrm{found} \mathrm{as} \mathrm{at}$ par with that of $2.5 \mathrm{~kg} \mathrm{Zn} / \mathrm{ha}+$ zinc solublizer, during both the years in grain and stover yield and during 2017 in biological yield, however, during 2016, in biological yield residual effect of $2.5 \mathrm{~kg} \mathrm{Zn} / \mathrm{ha}+$ zinc solubilizer statistically at par with that of $2.5 \mathrm{~kg} \mathrm{Zn} / \mathrm{ha}$ and $5 \mathrm{~kg}$ $\mathrm{Zn} / \mathrm{ha}$. The residual effect of zinc solublizer was also at par with $2.5 \mathrm{~kg} \mathrm{Zn/ha}$ in grain yield. Significant improvement in yield of this may also be ascribed to the auxin metabolism and increased photosynthetic rate and also due to increased starch, protein nitrogen, soluble protein and specific activity of carbonic anhydrase, specific activities of acid phosphatase and ribonuclease in leaves and pods by residues of zinc.

\section{Nutrient content}

Residual effect of different levels of phosphorous significantly increased the nitrogen and phosphorous contents of pearl millet grain and stover, over control up to 60 $\mathrm{kg} \mathrm{P}_{2} \mathrm{O}_{5} /$ ha that was significantly better over 20 and $40 \mathrm{~kg} \mathrm{P}_{2} \mathrm{O}_{5} /$ ha, during 2016 of nitrogen and during both the years of phosphorous, however, during 2017 that significant increase in nitrogen content was recorded only up to 40 $\mathrm{kg} \mathrm{P}_{2} \mathrm{O}_{5} /$ ha. Data presented in Table 1 reveal that residual effect of phosphorous levels brought non-significant variations in potassium and zinc contents of grain and stover of pearl millet, during both the years.

Increasing level of residual phosphorous had depressive effect on zinc content of grain and stover but such depression did not reach up to significant level and residual effect of $60 \mathrm{~kg}$ $\mathrm{P}_{2} \mathrm{O}_{5} /$ ha, resulted in the highest non-significant decrease in zinc content of grain and stover, during both the years. Availability of nitrogen also increased due to legume effect of preceding crop.

Cereals respond nitrogen and phosphorus to a great extent and increased availability of these nutrients in soil led to higher uptake of these nutrients which had a favourable effect on the growth of pearl millet. Solubility of residual phosphorus also increased due to intermittent wetting and drying conditions and higher temperature during the monsoon season. Because of these conditions, solubility of Ca-P in calcareous soils and diffusivity factor of phosphorus increased (Raju et al., 2005).

The highest increase in nitrogen content of grain and stover was obtained with the residual effect of $5 \mathrm{~kg} \mathrm{Zn/ha} \mathrm{+} \mathrm{zinc} \mathrm{solubilizer}$ and it was significantly better over all other treatments, during 2017, however, during 2016, when it was at par with $2.5 \mathrm{~kg} \mathrm{Zn/ha} \mathrm{+}$ zinc solubilizer. 
Table.1 Effect of residual phosphorous and zinc fertilization on nutrient contents of succeeding pearl millet

\begin{tabular}{|c|c|c|c|c|c|c|c|c|c|c|c|c|c|c|c|c|}
\hline \multirow[t]{3}{*}{ Treatments } & \multicolumn{4}{|c|}{ Nitrogen (\%) } & \multicolumn{4}{|c|}{ Phosphorous (\%) } & \multicolumn{4}{|c|}{ Potassium (\%) } & \multicolumn{4}{|c|}{ Zinc (ppm) } \\
\hline & \multicolumn{2}{|c|}{ Grain } & \multicolumn{2}{|c|}{ Stover } & \multicolumn{2}{|c|}{ Grain } & \multicolumn{2}{|c|}{ Stover } & \multicolumn{2}{|c|}{ Grain } & \multicolumn{2}{|c|}{ Stover } & \multicolumn{2}{|c|}{ Grain } & \multicolumn{2}{|c|}{ Stover } \\
\hline & 2016 & 2017 & 2016 & 2017 & 2016 & 2017 & 2016 & 2017 & 2016 & 2017 & 2016 & 2017 & 2016 & 2017 & 2016 & 2017 \\
\hline \multicolumn{17}{|c|}{ Phosphorous $\left(\mathbf{P}_{2} \mathrm{O}_{5} \mathrm{~kg} / \mathrm{ha}\right)$} \\
\hline 0.0 & 1.43 & 1.46 & 0.52 & 0.50 & 0.337 & 0.310 & 0.106 & 0.101 & 0.530 & 0.548 & 0.281 & 0.269 & 16.622 & 16.252 & 9.299 & 9.052 \\
\hline 20 & 1.54 & 1.56 & 0.60 & 0.57 & 0.372 & 0.349 & 0.126 & 0.120 & 0.535 & 0.553 & 0.285 & 0.273 & 16.241 & 15.876 & 9.107 & 8.865 \\
\hline 40 & 1.62 & 1.62 & 0.64 & 0.61 & 0.387 & 0.374 & 0.143 & 0.137 & 0.538 & 0.557 & 0.287 & 0.276 & 16.119 & 15.760 & 8.933 & 8.697 \\
\hline 60 & 1.68 & 1.66 & 0.67 & 0.64 & 0.397 & 0.392 & 0.152 & 0.146 & 0.539 & 0.559 & 0.288 & 0.276 & 16.086 & 15.674 & 8.861 & 8.626 \\
\hline SEm \pm & 0.01 & 0.02 & 0.01 & 0.01 & 0.004 & 0.004 & 0.001 & 0.002 & 0.010 & 0.009 & 0.004 & 0.003 & 0.193 & 0.292 & 0.233 & 0.201 \\
\hline $\mathrm{CD}(\mathrm{P}=0.05)$ & 0.05 & 0.05 & 0.03 & 0.02 & 0.015 & 0.014 & 0.004 & 0.005 & NS & NS & NS & NS & NS & NS & NS & NS \\
\hline \multicolumn{17}{|l|}{ Zinc(kg/ha) } \\
\hline 0.0 & 1.45 & 1.47 & 0.56 & 0.53 & 0.384 & 0.366 & 0.136 & 0.130 & 0.529 & 0.549 & 0.282 & 0.270 & 15.187 & 14.961 & 8.156 & 7.940 \\
\hline 2.5 & 1.54 & 1.55 & 0.60 & 0.57 & 0.365 & 0.349 & 0.129 & 0.124 & 0.533 & 0.554 & 0.285 & 0.273 & 15.929 & 15.603 & 8.782 & 8.549 \\
\hline$\overline{5.0}$ & 1.62 & 1.62 & 0.63 & 0.60 & 0.366 & 0.350 & 0.126 & 0.121 & 0.536 & 0.556 & 0.286 & 0.274 & 16.886 & 16.371 & 9.558 & 9.305 \\
\hline Zinc solubilizer & 1.50 & 1.51 & 0.58 & 0.55 & 0.378 & 0.361 & 0.134 & 0.128 & 0.529 & 0.550 & 0.281 & 0.269 & 15.667 & 15.434 & 8.398 & 8.175 \\
\hline $2.5+$ Zinc solubilizer & 1.62 & 1.63 & 0.63 & 0.60 & 0.374 & 0.357 & 0.133 & 0.127 & 0.541 & 0.559 & 0.288 & 0.276 & 16.625 & 16.193 & 9.509 & 9.257 \\
\hline 5.0 + Zinc solubilizer & 1.69 & 1.69 & 0.66 & 0.63 & 0.372 & 0.355 & 0.132 & 0.126 & 0.544 & 0.559 & 0.289 & 0.277 & 17.307 & 16.782 & 9.896 & 9.634 \\
\hline SEm \pm & 0.02 & 0.02 & 0.01 & 0.01 & 0.006 & 0.006 & 0.002 & 0.002 & 0.009 & 0.007 & 0.004 & 0.004 & 0.230 & 0.165 & 0.189 & 0.142 \\
\hline $\mathrm{CD}(\mathrm{P}=0.05)$ & 0.07 & 0.05 & 0.02 & 0.02 & NS & NS & 0.006 & NS & NS & NS & NS & NS & 0.658 & 0.471 & 0.543 & 0.406 \\
\hline
\end{tabular}


Table.2 Effect of residual phosphorous and zinc fertilization on nutrient uptakes by succeeding pearl millet

\begin{tabular}{|c|c|c|c|c|c|c|c|c|c|c|c|c|c|c|c|c|}
\hline \multirow[t]{3}{*}{ Treatments } & \multicolumn{4}{|c|}{ Nitrogen (kg/ha) } & \multicolumn{4}{|c|}{ Phosphorous $\left(\mathrm{P}_{2} \mathrm{O}_{5} \mathrm{~kg} / \mathrm{ha}\right)$} & \multicolumn{4}{|c|}{ Potassium $\left(\mathrm{K}_{2} \mathrm{O} \mathrm{kg} / \mathrm{ha}\right)$} & \multicolumn{4}{|c|}{ Zinc (g/ha) } \\
\hline & \multicolumn{2}{|c|}{ Grain } & \multicolumn{2}{|c|}{ Stover } & \multicolumn{2}{|c|}{ Grain } & \multicolumn{2}{|c|}{ Stover } & \multicolumn{2}{|c|}{ Grain } & \multicolumn{2}{|c|}{ Stover } & \multicolumn{2}{|c|}{ Grain } & \multicolumn{2}{|c|}{ Stover } \\
\hline & 2016 & 2017 & 2016 & 2017 & 2016 & 2017 & 2016 & 2017 & 2016 & 2017 & 2016 & 2017 & 2016 & 2017 & 2016 & 2017 \\
\hline \multicolumn{17}{|c|}{ Phosphorous $\left(\mathrm{P}_{2} \mathrm{O}_{5} \mathrm{~kg} / \mathrm{ha}\right)$} \\
\hline 0.0 & 24.17 & 21.89 & 23.36 & 18.07 & 12.84 & 10.53 & 10.66 & 8.36 & 10.65 & 9.79 & 14.91 & 11.66 & 27.85 & 24.24 & 41.49 & 32.79 \\
\hline 20 & 28.69 & 25.68 & 28.80 & 23.07 & 15.78 & 13.04 & 13.83 & 11.07 & 11.93 & 10.88 & 16.40 & 13.20 & 30.24 & 26.02 & 43.89 & 36.00 \\
\hline 40 & 36.78 & 31.95 & 35.65 & 29.69 & 19.95 & 16.74 & 18.07 & 15.05 & 14.49 & 13.08 & 19.03 & 15.89 & 36.58 & 31.02 & 49.51 & 42.16 \\
\hline 60 & 43.37 & 37.20 & 41.50 & 34.09 & 23.33 & 19.96 & 21.44 & 17.72 & 16.69 & 15.00 & 21.26 & 17.60 & 41.55 & 35.18 & 54.77 & 46.09 \\
\hline SEm \pm & 0.94 & 0.87 & 0.33 & 0.46 & 0.26 & 0.26 & 0.38 & 0.33 & 0.47 & 0.44 & 0.43 & 0.40 & 0.96 & 0.82 & 1.30 & 0.63 \\
\hline $\mathrm{CD}(\mathrm{P}=0.05)$ & 3.24 & 3.01 & 1.16 & 1.60 & 0.91 & 0.91 & 1.30 & 1.15 & 1.63 & 1.52 & 1.48 & 1.40 & 3.32 & 2.83 & 4.51 & 2.17 \\
\hline \multicolumn{17}{|l|}{ Zinc(kg/ha) } \\
\hline 0.0 & 25.75 & 22.14 & 26.76 & 20.75 & 15.59 & 12.70 & 14.97 & 11.66 & 11.15 & 9.90 & 15.84 & 12.49 & 26.53 & 22.40 & 38.07 & 30.45 \\
\hline 2.5 & 30.30 & 26.53 & 30.62 & 24.07 & 16.48 & 13.78 & 15.21 & 12.03 & 12.50 & 11.33 & 17.31 & 13.71 & 31.05 & 26.41 & 44.42 & 35.72 \\
\hline 5.0 & 36.26 & 32.51 & 35.38 & 28.13 & 18.82 & 16.15 & 16.38 & 13.21 & 14.32 & 13.28 & 19.08 & 15.30 & 37.36 & 32.55 & 53.06 & 43.03 \\
\hline Zinc solubilizer & 29.08 & 24.96 & 28.16 & 21.87 & 16.73 & 13.72 & 15.09 & 11.71 & 12.24 & 10.87 & 16.23 & 12.72 & 29.90 & 25.23 & 40.24 & 31.90 \\
\hline $2.5+$ Zinc solubilizer & 35.39 & 30.87 & 33.85 & 29.09 & 18.67 & 15.61 & 16.33 & 14.11 & 14.08 & 12.68 & 18.39 & 15.83 & 35.94 & 30.41 & 50.20 & 43.90 \\
\hline $5.0+$ Zinc solubilizer & 42.75 & 38.06 & 39.19 & 33.47 & 21.55 & 18.46 & 18.01 & 15.58 & 16.35 & 15.07 & 20.56 & 17.48 & 43.55 & 37.70 & 58.48 & 50.57 \\
\hline SEm \pm & 1.21 & 0.82 & 0.85 & 0.80 & 0.52 & 0.38 & 0.54 & 0.50 & 0.47 & 0.34 & 0.57 & 0.48 & 0.94 & 0.74 & 1.55 & 1.25 \\
\hline $\mathrm{CD}(\mathrm{P}=0.05)$ & 3.45 & 2.36 & 2.44 & 2.27 & 1.49 & 1.09 & 1.53 & 1.44 & 1.34 & 0.98 & 1.62 & 1.37 & 2.69 & 2.12 & 4.43 & 3.56 \\
\hline
\end{tabular}


Fig.1 Mean weekly weather parameters for kharif crop season (Pearl millet)

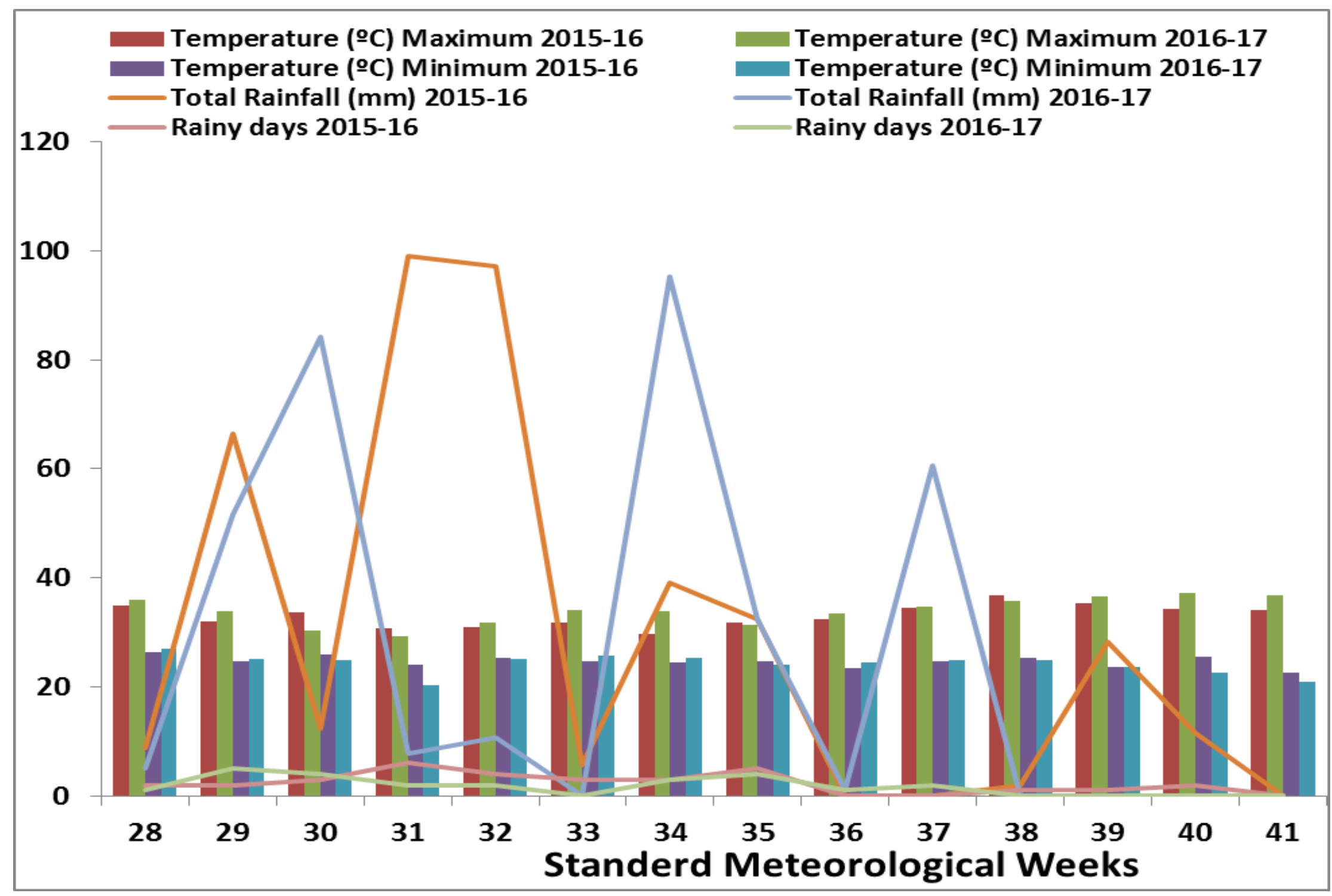


Residual effect of $5 \mathrm{~kg} \mathrm{Zn} / \mathrm{ha}$ was significantly superior over $2.5 \mathrm{~kg} \mathrm{Zn/ha,} \mathrm{zinc}$ solubilizer and control but statistically at par with $2.5 \mathrm{~kg} \mathrm{Zn} / \mathrm{ha}+$ zinc solubilizer, during both the years. The phosphorous content in stover, during 2016 was significantly influenced due to residual effect of various zinc treatments, however, during rest of the years this effect was found non-significant. The phosphorous content of grain and stover decreased with the residual effect of zinc treatments, however, the residual effect of 2.5 $\mathrm{kg} \mathrm{Zn} / \mathrm{ha}$ and $5 \mathrm{~kg} \mathrm{Zn} / \mathrm{ha}$ exhibiting significantly lower content than control. Though these two treatments remained as at par in this regard. The highest zinc content of grain and stover was recorded with the residual effect of $5.0 \mathrm{~kg} \mathrm{Zn} / \mathrm{ha}+$ zinc solubilizer followed by $5 \mathrm{~kg} \mathrm{Zn} / \mathrm{ha}$. During 2016, residual effect of $5 \mathrm{~kg} \mathrm{Zn} / \mathrm{ha}$, significantly improved the zinc content of grain over control, zinc solubilizer and $2.5 \mathrm{~kg}$ $\mathrm{Zn} / \mathrm{ha}$ but it was at par with that of $2.5 \mathrm{~kg}$ $\mathrm{Zn} / \mathrm{ha}+$ zinc solubilizer and $5 \mathrm{~kg} \mathrm{Zn} / \mathrm{ha}+$ zinc solubilizer. Zinc content of grain, during 2017 significantly improved with residual effect of $2.5 \mathrm{~kg} \mathrm{Zn} / \mathrm{ha}+$ zinc solubilizer but was at par only with that of $5 \mathrm{~kg} \mathrm{Zn} / \mathrm{ha}$. Residual effect of $2.5 \mathrm{~kg} \mathrm{Zn} / \mathrm{ha}+$ zinc solubilizer was significantly influence the zinc content of stover, during both the years, over zinc solubilizer and $2.5 \mathrm{~kg} \mathrm{Zn/ha} \mathrm{but} \mathrm{was} \mathrm{at} \mathrm{par}$ with that of $5 \mathrm{~kg} \mathrm{Zn} / \mathrm{ha}$ and $5 \mathrm{~kg} \mathrm{Zn} / \mathrm{ha}+$ zinc solubilizer. The residual effect of zinc solubilizer had no significant effect on nitrogen and zinc contents and all zinc treatments on potassium content of grain and stover, during both the years. In dry land areas zinc application increases absorption of minerals by roots (Singh et al., 2017). Nourishment with zinc helps in improving nitrogen content of plant through biological nitrogen fixation (BNF) though, nitrogen appears to be synergistic with zinc, which may leads to increase in many physiological and molecular activities which in turn improve content of these nutrients in grain and stover (Cakmak et al., 2010). Further, zinc availability is also increased, during rainy season due to increased temperature and intermittent wetting and drying of soil due to rains and dry spells owing to temporal variations in rains in monsoon season (Raju et al., 2005) as evidenced by environmental conditions of rainy season as observed in form of dry spells (14 and 28 days, during 2016 and 2017, respectively).

\section{Nutrient uptake}

Grain and stover uptake of nitrogen, phosphorous, potassium and zinc by pearl millet (Table 2) increased significantly with increasing levels of residual phosphorous and the highest uptake values for these were recorded with the effect of $60 \mathrm{~kg} \mathrm{P}_{2} \mathrm{O}_{5} / \mathrm{ha}$ and that was significantly superior over preceding levels, during both the years. However, potassium and zinc uptake by grain, during both the years, and zinc uptake by stover, during 2016 not influenced significantly with $20 \mathrm{~kg} \mathrm{P}_{2} \mathrm{O}_{5} / \mathrm{ha}$.

Further, data embodied in Table 2, shows that residual effect of different zinc treatments significantly enhanced nitrogen, phosphorous, potassium and zinc uptakes by grain and stover of succeeding crop, over control except zinc solublizer that nitrogen uptake by grain, during 2016 and nitrogen and zinc uptake by stover, during both the years. The highest nitrogen, phosphorous, potassium and zinc uptakes by grain and stover were recorded under the residual effect of $5 \mathrm{~kg} \mathrm{Zn/ha} \mathrm{+} \mathrm{zinc}$ solublizer that was significantly superior over rest of the treatments followed by $2.5 \mathrm{~kg}$ $\mathrm{Zn} / \mathrm{ha}+$ zinc solublizer, during both the years. Residual effect of $2.5 \mathrm{~kg} \mathrm{Zn} / \mathrm{ha}+$ zinc solublizer was significantly better than zinc solublizer and $2.5 \mathrm{~kg} \mathrm{Zn} / \mathrm{ha}$ but statistically at par with $5 \mathrm{~kg} \mathrm{Zn/ha} \mathrm{in} \mathrm{improving} \mathrm{the} \mathrm{nitrogen}$ uptake by grain and stover, during both the 
years. However, nitrogen and zinc uptake by grain, during 2016 and phosphorous uptake by grain, during both the years, significantly enhanced with zinc solublizer, over control but statistically at par with $2.5 \mathrm{~kg} \mathrm{Zn} / \mathrm{ha}$. The effect of $5 \mathrm{~kg} \mathrm{Zn/ha} \mathrm{+} \mathrm{zinc} \mathrm{solubilizer} \mathrm{in}$ terms of phosphorous uptake by stover, during 2017 was followed by $5 \mathrm{~kg} \mathrm{Zn/ha,}$ however, later treatment effect was observed as at par with $2.5 \mathrm{~kg} \mathrm{Zn} / \mathrm{ha}+$ zinc solubilizer, for all such responses. The significant increase in potassium uptake by stover observed with residual effect of $5 \mathrm{~kg} \mathrm{Zn} / \mathrm{ha}$, over control but it was at par with that of 2.5 $\mathrm{kg} \mathrm{Zn/ha} \mathrm{+} \mathrm{zinc} \mathrm{solubilizer} \mathrm{and} 5 \mathrm{~kg} \mathrm{Zn/ha} \mathrm{+}$ zinc solubilizer during 2016, however, during 2017, only effect of $2.5 \mathrm{~kg} \mathrm{Zn} / \mathrm{ha}+$ zinc solubilizer was at par with $5 \mathrm{~kg} \mathrm{Zn/ha.}$

Nitrogen, phosphorous, potassium and zinc uptakes by succeeding pearl millet crop increased significantly and this could be attributed to increased contents of these nutrients in grain and stover and increased production of pearl millet with the increasing levels of residual phosphorous and zinc applied to preceding fenugreek crop (Table 2).

The cultivation of legumes increased the soil organic matter due to its litter fall which extensive root system decomposed into organic matter (Hayat et al., 2008). Experimental evidences from different agroecological regions have clearly demonstrated that phosphorous application to legumes not only benefited that such crop but also favourably affected the nitrogen content of soil for succeeding non-legume crop of soil (Ganeshamurthy et al., 2003). Similar results also reported by Ullah et al., (2015) in rice wheat cropping sequence. Despite of marginal depressive effect of zinc on phosphorous absorption, greater availability of phosphorous due to its application adequate nutrient was available.
Residual effect of $60 \mathrm{~kg} \mathrm{P}_{2} \mathrm{O}_{5} / \mathrm{ha}$ and $5.0 \mathrm{~kg}$ $\mathrm{Zn} / \mathrm{ha}+$ zinc solubilizer were significantly effective in improving yield, nutrient content and their uptake by succeeding pearl millet.

\section{References}

Cakmak, I., Pfeiffer, W. H. and Mc Clafferty, B. 2010. Bio fortification of durum wheat with zinc and iron. Cereal Chem. 87: 10-20.

Ganeshamurthy, A. N., Sriniwasrao, C. H., Singh, K. K. and Ali, M. 2003. Management of phosphorous for higher pulse productivity in different agroclimatic regions of India. Fertilizer News 48 (5): 23-27, 27-34 \& 37-41

Hayat, R., Safdar, A., Muhammed, T. S. and Chatha, H. T. 2008. Biologal nitrogen fixation of summer legumes and their residual effects on subsequent rainfed wheat yield. Pakistan Journal of Botany. 40 (2): 711-722.

Jat, B. L. and Shaktawat, M. S. 2003. Effect of residual phosphorus, sulphur and biofertilizers on productivity, economic returns and nutrient content of pearl millet (Pennisetum glaucum) in fenugreek [Trigonella foenum-graecum (L.)] - pearl millet cropping sequence. Indian Journal of Agricultural Sciences 73 (3): 134-137.

Mehta, R. S., Patel, B. S. and Jat, R. A. 2011. Effect of Nitrogen, Phosphorus and BioFertilizer inoculation on Growth, Productivity, Nutrient Uptake and Economic Returns in Fenugreek (Trigonella foenum-Graecum L). Indian Journal of Dryland Agriculture Research and Development 26 (1): 102108

Raju, R. A., Subba Rao, A. and Rupa, T. R. 2005. Strategies for integrated phosphorous management for sustainable crop production. Indian Journal of Fertilizer 1: 25-28 \& 31-36 
Singh, A., Singh, S. P., Mahawar, A. K. and Yadav, T. V. 2015b. Influence of different plant bio regulators and zinc levels on yield attributes and economics of fenugreek (Trigonellafoenum graecum L.) under semi-arid conditions. Progressive Horticulture 47 (1): 151153.

Takkar, P. N. 1996. Micronutrient research and sustainable agricultural productivity in India. J. Indian Soc. Soil Sci. 44 (4): $562-581$

Ullah, A., Ullah, I., Nawab, K. and Shah, Z. 2015. Preceding rice genotypes, residual phosphorus and zinc influence harvest index and biomass yield of subsequent wheat crop under rice-wheat system. Pakistan Journal of Botany 47(SI): 265273.

\section{How to cite this article:}

Kumawat, S., R. Sammauria and Kumawat Pushpa. 2018. Residual Phosphorus and Zinc Influence on Succeeding Pearl Millet (Pennisetum glaucum) under Rainfed Conditions of Arid Region of Rajasthan. Int.J.Curr.Microbiol.App.Sci. 7(09): 1214-1222.

doi: https://doi.org/10.20546/ijcmas.2018.709.145 